\title{
Pesantren understanding on halal product guarantee
}

\author{
A.M. Nasih* \& A. Sultoni \\ Universitas Negeri Malang, Malang, Indonesia
}

\begin{abstract}
This study investigates pesantren people's understanding of halal products and halal product guarantee systems according to Law No. 33, of the Year 2014. These people's comprehension of halal products is essential since considering their substantial number, they held a considerable role in realizing the government-designated halal product guarantee system. This study used descriptive qualitative design classified as field research. The analysis results identify that pesantren people utilize the Islamic law (Figh) standards and understanding to ensure whether a product is halal. Those understandings and standards transform into the fundamental value that establishes the halal value chain in pesantren. Therefore, pesantren people own immense comprehension and awareness of the halal product. However, in relation to the halal product guarantee system determined by the government, pesantren still needs socialization and capacity development.
\end{abstract}

Keywords: pesantren, halal product, Islamic law

\section{INTRODUCTION}

The availability or clarity of information regarding the halal status of food, cosmetics, fashion, medicines, or other consumers' goods remains crucial for Muslims (Charity 2017). From the consumer's perspective, it involves faiths and religious doctrines (Ruslan et al. 2018), as well as human rights. Islam instructs only to have halalan-thayyiban (QS al-Baqarah [2]: 168). Foods designated so are halal, hygienic, and good for our health (Wibowo et al. 2020). Further, in the current modern era, the manufacturing industry has experienced significant development, along with the growth in science and technology. The increasing production in this sector has raised concerns about the quality of their products.

Consequently, as a form of consumer protection, the Indonesian government enacted Law No. 33 of the Year 2014 on a halal product guarantee, which is regulated in Government Regulation No. 31 of the Year 2019. The enactment of these regulations is important since it responds to the global demand on the halal industry (a global halal trend), and it shifts Indonesian halal certification from community-centric into state-centric (Akim et al. 2019). Previously, people or businessmen would indicate halal certification on their products to enhance their brand. Currently, that obligation has shifted onto the government. The government must ensure the quality of all products in Indonesia through halal certification. Besides, the government also ensures that each religious follower can worship and practice their religion safely through the halal guarantee for the products used and consumed by society.

The state-centric certification system relocation, as mentioned in paragraph 30 article 3 Government Regulation No. 31 of the Year 2019, creates an opportunity for the government to have corporation with society or religious institutions with legal certification. Thus, one of the influential entities that should be the government focus on implementing a halal product guarantee system is pesantren.

Pesantren is an inseparable institution from Muslims in Indonesia since Indonesia's growth and development are part of Islam's development (Shaleh 1982). Its presence as an Islamic religious

*Corresponding author 
institution has been proven strategic (Haningsih 2008) to shape clerics with in-depth spiritual knowledge, as well as awareness, skill, and concern of public issues (Haningsih 2008; Nasih 2014). In addition, pesantren is also productive in constructing Islamic regulations through a fatwa as an effort to solve the problems that appeared in society (Nasih 2014). Pesantren frequently refers to turats books in determining the regulations (Nasih 2014). Those regulations also include specifying the halal level of foods and beverages. This study aims to investigate pesantren people's comprehension of halal products and the halal product guarantee system regulated in Law NO. 33 of the Year 2014. Their comprehension is essential since they have a considerable number of resources that can help to implement the regulation.

\section{METHODS}

This research used qualitative method classified as field research and was carried out in middle of 2020. The research subjects are five pesantren in East Java categorized as modern (pesantren Attanwir), semi-modern (pesantren Bahrul Maghfiroh), and Salafi (pesantren Assuniyah and Lirboyo). The data were obtained through interviews, observation, and documentation. The obtained data was analyzed using content analysis suggested by Klaus Krippendorff (1993). The data analysis stages involve unitizing the data selected for research sources, sampling from various information and data sources, reducing, inferring, analyzing, and narrating. The analyzed data was presented and commented on in the research results and conclusion.

\section{RESULTS AND DISCUSSION}

\subsection{Pesantren as a living discourse}

Historically, pesantren has a continuously developing definition. The definition changes following society's needs. However, it has two primary functions as an educational and socio-religious institution. The changes are usually fundamental and practical. Formerly, people come to pesantren only to learn Islamic teaching and ways to recite the Qur'an. Currently, however, they also go to pesantren to get formal education because of job reason. Therefore, in the future, people will need pesantren of economic factor. This is because pesantren, as illustrated by Marzuki Wahid, is a living discourse. Therefore, discussion about pesantren is always fresh, alluring, practical, and difficult since it is multidimensional (Marzuki 1999). Marzuki explains that even with its multidimensional features, pesantren has the confidence and self-defense to face outside challenges (Marzuki 1999).

Pesantren is known as a traditional educational institution, but with its features and resources, it develops the most robust survival mechanisms in facing modern challenges. Thus, society often sees it as the best alternative to facing life challenges, including becoming the primary reference to conducting daily activities, primarily those related to Islamic principles and teachings. This is illustrated in perspective from Abdurrahman Wahid (Gus Dur) that cultural conservation is reflected in the pesantren intellectual tradition. The lessons offered in pesantren are in the form of universal literature through the guidance and blessings of kyai as the primary teacher (irsyadu ustazin). The universal literature is in the form of yellow books, maintained and transmitted intergenerationally, and directly related to the unique concept of kyai leadership. The lessons contained ancient books (seen from a modern perspective) promise the right tradition (al-qadimi ash-shalih) and preserve the religious knowledge widely given to Muslims by past great clerics.

\subsection{Map of pesantren comprehension on halal product guarantee system}

Pesantren owns two primary functions as an educational and socio-religious institution. As an educational institution, it facilitates the teaching of religious knowledge such as the Qur'an, hadith, Arabic, aqidah, and fiqh (Fathoni 2005). Meanwhile, as a socio-religious institution, people who 
need the pesantren head into social and economic projections that become their fundamental needs (Marzuki 1999). Besides, kyai is an economically independent figure. Thus, the students (santri) in pesantren are also independent; in their tradition, they take care of themselves fully, from their consumption to their accommodation. In the fifth model, pesantren, santri are allowed to manage the kitchen, canteen, grocery store, and other related activities. In other words, without the parents, santri can live independently with their friends in pesantren (Zarkasyi 2015).

In the religious understanding context, such as deciding the halal and haram status of acts, foods, and beverages, pesantren possess an excellent understanding that is implemented in their daily life. This condition differentiates pesantren from other educational institutions in Indonesia. The other factors that differentiate them are that pesantren provide boarding houses (pondok) for the student's accommodation, their students are known as santri, the mosque used as a praying facility and a center for activities, kyai as a figure with religious competence and great charisma, and well as yellow books as the primary literature for Islamic studies (Syafe'i 2017).

Salafi pesantren or traditional pesantren are those who maintain learning using classic books with no general knowledge. The learning models commonly implemented in this pesantren isare Sorogan, Wetonan, and Bandongan (Anhari 2007; Dhofier 1985; Qomar 2005). This pesantren remains connected to the ancient pesantren or known as Salafi pesantren. This pesantren has several characteristics. First, its main activity is the literal study of classic books. Second, the method used in this pesantren is traditional methods, such as sorogan, wetonan, and memorization. Third, it does not use a structured class system in a study period, so that the learning achievement of santri is measured based on the number of books they have learned and with which cleric they learn it. Fourth, it the educational aim is to improve morals in acts and behaviors, as well as preparing the santri to implement the knowledge and morals in their daily life (Zarkasyi 2015).

Within the halal product guarantee system that has been implemented in pesantren, they use the fiqh standards that they have learned in the yellow books. Assunniyah Pesantren Kencong Jember is a Salafi pesantren. The institution was established in 1942 by K.H. Djauhari Zawawi in Kencong village, around 500 meters from the Kencong district office and 45 kilometers in the southwest of the center of Jember city. If a pesantren implements an educational system, then it uses a traditional (madrosi) system that consists of ibtidaiyah (elementary), tsanawiyah (secondary), and 'aliyah (secondary). From those three education levels, the books remain are used in accordance with the santri's capability.

For the legal and Sharia (fiqh) learning, pesantren decides the books that should be learned, such as Fathul Mu'in, Tahrir, Fathul Wahab, as well as other mu'tabaroh books. Therefore, even in legal determination, those books are still used. For instance, in the determination of animals to be consumed, such as chicken, the committee of Assunniyah Pesantren Kencong Jember believe that the animal sold in the market around the pesantren are halal if the seller is Muslim, and it is also located in the Islamic area (darul Islam).

For us, any doubt about an animal in an Islamic area (darul Islam) should be erased, since it should be halal, as explained in al-asylum fi alasyya' al hillu (the origin of things is halal) principle. However, if it is in an area with a non-Muslim majority, the doubt should be perceived as haram.

(Interview by Musthofa 2020)

The same thing is also considered by the santri in evaluating food and clothing. The pesantren cooperate to fulfill the santri daily needs. The fulfillment of some requirements also involves the surrounding society. The santri also understand which product is halal or haram in selecting foods or beverages. Besides, each product provided in the cooperative is selected by the pesantren management. For example, a perfume with alcohol above the standard is prohibited from being traded in the cooperative. Meanwhile, for the standards of the halal product guarantee enacted by the government, the pesantren have not understood it since they have not received socialization.

The same finding was also found at other Salafi pesantren, Lirboyo Pesantren Kediri, East Java. Lirboyo is the name of a village used as the pesantren's name. The history of this pesantren 
cannot be separated from its founder KH. Abdul Karim, who moved and stayed in this village since 1910. Other than being the center of Islamic education, Lirboyo is also well-known as Salafi pesantren that is successful in combining tradition that complete the modernity and has brought many religious-pious and socially pious figures.

According to the statement of one senior cleric (Interview by Ali Muntaqo 2020), even if it is as famous as Salafi pesantren, Lirboyo possesses various educational systems. The system used depends on the policy of the tutor and management in every unit. However, even if the implemented methods are different, all units must comply with the Welfare Development Body of the Lirboyo Pesantren. This body has the highest authority in the Lirboyo Pesantren. Every activity or policy in the boarding house or school can only be realized if it is approved by that body. If there is an unresolved issue in the central or unit of the pesantren, then it is taken to the Welfare Development Body of the Lirboyo Pesantren meeting.

Other than that body, the educational system is also managed by the Deliberative Council of Lirboyo Pesantren that is now called the Lajnah Bahtsul Masail of Lirboyo Pesantren. This council also produces legal fatwas. This council has the most considerable strategy role for three main reasons: first, it acts as a mediator in socializing new ideas of Islamic understanding to society. Second, it functions as a body that sharpens the skills, creativity, and intellectual quality of the santri in various religious sciences, primarily fiqh. Third, it prepares competent santri in accommodating different thought in society and formulate a sensible and wise decision.

In the halal product guarantee, Lirboyo has completed studies on some food, fashion, and medical products. As explained by Ali Muntaqo (2020), Lajnah Bahtsul Masail of Lirboyo Pesantren always publishes books from the legal discussion (bahtsul masail) in each educational level. In other words, the body has unique authority in deciding and regulating policy, including the halal status of a product. Further, after the regulation or new ideas on Islamic teaching has been enacted, it is socialized to the society through guideline books or directly delivered in da'wah. Interestingly, this body has also published a book entitled, Medical Fiqh: Study of Sharia Law, History and Lesson in Medical World. Like the Assuniyah Pesantren Jember, Lirboyo Pesantren also has not technically understood the standards of the halal product guarantee regulation. However, they have decided the standards for halal product guarantee to determine the halal status of a product.

Semi-modern pesantren is pesantren combining Salafi and Khalaf pesantren. The pesantren conduct its education with a hybrid system. It uses traditional book learning with formal madrasa and adopts a government curriculum (Alwi 2013). In other words, a semi-modern pesantren integrates traditional and modern pesantren. Other than the traditional pesantren curriculum, the classic book learning in this pesantren also uses the Ministry of Religious Affairs curriculum and the Ministry of Education curriculum (Syafe'i 2017). This kind of pesantren keeps its Salafi part by the study of classics books, and the Khalaf aspect of this pesantren is reflected from its formal education such as madrasa, schools, and universities. The study of classical books is obligatory for all of its santri in all levels of education, even if some of the santri only join the classical books study. This pesantren also provides non-formal Islamic education (Majelis Taklim) and vocational education (Zarkasyi 2015).

In this study, Bahrul Maghfiron Pesantren, Malang was selected as representation of a semimodern pesantren. This pesantren was pioneered in 1995; however, it was built in 1997, simultaneously with the inauguration of Mbah Kiai Fattah Mosque, as the founding father of the pesantren. He later appointed his son, Lukman Al Karim bin Abdullah Fattah as the head of the tutor. This pesantren develops several methods, including traditional methods, such as sorogan and wetonan, as well as the combination method by learning various mu'tabarah books that are frequently used by Ahlussunna wal jamaah clerics.

In addition, Bahrul Maghfiron Pesantren also develops economic sectors through businesses. The developed businesses use standards explained in yellow books. In other words, they understand the products to be developed in accordance with the Islamic Sharia. Therefore, the established business units mostly used Sharia labels, such as BM (Bahrul Maghfiroh) Kitchen as a business unit of the Sharia Cooperative owned by Bahrul Maghfiroh Al-Fattah As-Syafi'iyah Foundation. Other than 
to improve the pesantren economy, BM Kitchen also focusses on home cooking that is pleasant, inexpensive, and halalan thoyyiban based on Islamic Sharia. BM Kitchen started to operate on October 9, 2018 and was inaugurated by East Java Governor Hj. Khofifah Indar Parawansa on November 9, 2018. In addition to BM Kitchen, they also have Bahrul Maghfiroh Mart (BM Mart), a grocery store that aims to realize an independent economy that aids the pesantren operational cost. This store has not been affiliated with halal companies, but its products are halal products produced by small and medium enterprises.

Additionally, it also develops BM Urban Farming in the agricultural sector. By using the hydroponics method, it utilizes a $12 \times 8$ meters area as agrarian land with 5000 holes. The plants produced by them include red spinach, green spinach, red lettuce, kale, celery, and so forth. The superiority of hydroponic vegetables is because they are healthier, pesticide-free and more nutritious. Besides, the hydroponics method also preserves the halal level of the products.

Modern pesantren, or known as Khalaf pesantren, also implement classic learning (madrasa), provide general and religious sciences, as well as provide vocational education. This pesantren has undergone modernization in its educational system, institutional system, speculation, and function, along with technological support and proper foreign language institution (Zarkasyi 1998). In relation to this, ma'had aly is also categorized as modern pesantren.

In addition, the modern pesantren provides a library, a public kitchen, a living room, a dining room, an administrative office, a grocery store or cooperative, a meeting hall, a toilet, and adequate laboratory. The activity in modern pesantren involves book study, madrasa, and public elementary school to university activity, as well as vocational education and environmental development education (Saridjo 1979).

Attanwir Talun Pesantren, Bojonegoro, was selected as representation of modern or kholaf pesantren. It was established in 1993 by KH. M. Sholeh. Formerly, it only taught the children to fluently recite the Qur'an, writing in Arabic, and prayer procedures, which are currently only found in pesantren with the wetonan system. In 1951, this pesantren started to use the classical learning system by creating diniyah classes with a two-year learning period. Later, in 1954, its religious educational system developed into Madrasa Ibtidaiyah with 6 years of learning. Then, to accommodate the Madrasa Ibtidaiyah graduates, it established Madrasah Mu'allimin Al-Islamiyah with a 4-year study period in 1961. Following the advancement and demand that are continuously growing, it was changed into Madrasa Tsanawiyah Islamiyah for 3 years and Madrasa Aliyah Islamiyah for 3 years, as well all Sekolah Tinggi Agama Islam (STAI) Attanwir. All the Islamic learning processes, including fiqh, in those levels, are perceived to be sufficient to guide the santri to live in a society (Interview by Sahal 2020).

In relation to the halal product guarantee, Attanwir Pesantren has implemented a system a long time ago. This system follows the fiqh that has been taught to the santri. Besides, Attanwir Pesantren has also implemented Halal Mart that provides foods and medical products for the santri.

Pesantren has credible religious integrity, including the products produced by the pesantren. For
instance, Attanwir had always produced halal beverages, however, the production cannot be continued.
The santri consumption is managed by the pesantren's canteen based on the standards we have The santri consumption is managed by the pesantren's canteen based on the standards we have
(Interview by Sahal 2020).

Sahal (2020) also mentioned that Attanwir always maintains the quality of food consumed by the santri, including the purchase of the consumed animal. Every purchase of meat, even if it is rare, is always done with a pesantren graduate Muslim seller who knows how to slaughter animals based on Sharia (Interview by Sahal 2020). Consequently, the pesantren understands the halal level of santris' needs, as well as society's needs of the pesantren integrity as a religious, educational and Islamic institution.

Additionally, Attanwir Pesantren has also opened the Halal Network International (HNI) business center store which is affiliated with Herba Penawar Alwahida Indonesia (HPAI). It is managed by an administrator in the Rumah Sehat LKSM Attanwir office (Interview by Muflihatin 2020). Further, this pesantren has also developed waste management to empower santris' economy by producing fertilizer, crafts, and so forth. The organic waste was managed into fertilizer. While, for the crafts, 
the inorganic waste, such as paper, plastics, and so forth, were used. In other words, the waste went through a feasibility test before the production process. For the regulation related to the halal product guarantee enacted by the government, Attanwir has even received an invitation to send its delegate to join the Halal Product Guarantee training in a university in Surabaya. However, due to the time and condition constraints, the pesantren did not send its representative (Interview by Sahal 2020).

\section{CONCLUSION}

The Salaf, semi-modern, and modern pesantren have properly comprehended the halal and haram standards for food and beverages products. As mentioned in Islam, all foods and beverages are halal, except those declared harams, such as corpses, blood, pork, and animals slaughtered not in the name of Allah (QS Al-Baqarah [2]: 173). Meanwhile, haram beverages include all forms of drinks that contain alcohol (QS. Al Baqarah [2]: 219). This idea has been adequately understood by the pesantren people following their studies on relevant classic books. The study of classic book in the pesantren has become fundamental aspect in ensuring that every good consumed or used is halal. It is proven that those understandings become the base in establishing halal chain value in pesantren. In other words, pesantren has excellent awareness of halal products. However, in relation to the halal product guarantee regulation enacted by the government, further socialization is still required to develop the capacity.

\section{REFERENCES}

Akim, N. K.; Chandra, P. \& Leej, C.K. 2019. The Shifting of Halal Certification System in Indonesia: From Society-Centric to State-Centric, MIMBAR, Vol. 35 No. 1st: 115-126.

Alwi, B.M. 2013. Pondok Pesantren: Ciri Khas, Perkembangan, dan Sistem Pendidikannya. Lentera Pendidikan Vol. 16, No. 2: 205-219.

Anhari, M. 2007. Integrasi Sekolah ke dalam Sistem Pendidikan Pesantren. Surabaya: Diantama.

Charity, M.L. 2017. Jaminan Produk Halal di Indonesia. Jurnal Legislasi Indonesia Vol. 14 No. 01 — Maret: 99-108.

Dhofier, Z. 1985. Tradisi Pesantren: Studi Tentang Pandangan Hidup Kyai. Jakarta: LP3ES.

Fathoni, M.K. 2005. Pendidikan Islam dan Pendidikan Nasional: Paradigma Baru. Jakarta: Direktorat Jenderal Kelembagaan Agama Islam.

Haningsih, S. 2008. Peran Strategis Pesantren, Madrasah dan Sekolah Islam di Indonesia. El Tarbawi: Jurnal Pendidikan Islam No. 1. Vol. I: 27-39.

Sahal, M. Rafiq, Interview in Pondok Pesantren Attanwir Talun Bojonegoro. 28 June 2020. Krippendorff, K. 1993. Analisis Isi Pengantar Teori dan Metodologi. Jakarta: Raja Grafindo.

Marzuki, W., (etc.) 1999. Pesantren Masa Depan: Wacana Pemberdayaan dan Transformasi Pesantren. Jakarta: Pustaka Hidayah. Muflihatin, Siti Imaniatul, Interview in home of alumni Pondok Pesantren Attanwir Talun Bonojegoro, 29 June 2020.

Muntaqo, Ali, Interview in Pondok Pesantren Lirboyo Kediri. 5 July 2020.

Musthofa, Interview in Pondok Pesantren As-Suniyah Kencong Jember. Sunday, 21 June 2020.

Nasih, A.M. 2014. Pemaknaan masyarakat santri atas fatwafatwa keagamaan produk pesantren. Ijtihad: Jurnal Wacana Hukum Islam dan Kemanusiaan Volume 14, No. 1, Juni: 119-138.

Qomar, M. 2005. Pesantren dari Transformasi Metodologi Menuju Demokratisasi Institusi, Jakarta: Erlangga.

Ruslan, A. A. A., Kamarulzaman, N. H. \& Sanny 2018. Muslim consumers' awareness and perception of Halal food fraud. International Food Research Journal 25 (Suppl.1), December: S87-S96.

Saridjo, M. 1979. Sejarah Pondok Pesantren di Indonesia. Jakarta: Dharma Bhakti.

Shaleh, A.R. (etc.) 1982. Pedoman Pembinaan Pondok Pesantren Jakarta: Proyek Pembinaan dan Bantuan Pondok Pesantren.

Syafe'i, I. 2017. Pondok Pesantren: Lembaga Pendidikan Pembentukan Karakter. Al-Tadzkiyyah: Jurnal Pendidikan Islam 8 (1): 61-82.

Wibowo, M.M., Hanafiah, A., Ahmad, F.S., Khairuzzaman, W. 2019. Introducing Halal Food Knowledge to the Non-Muslim Consumers in Malaysia (Its Effect on Attitude and Purchase Intention). Advances 
in Economics, Business and Management Research Volume 120, 4th International Conference on Management, Economics and Business (ICMEB).

Zarkasyi, A.S. 1998. Langkah Pengembangan Pesantren dalam Rekontruksi Pendidikan dan Tradisi Pesantren Religiusitas Iptek. Yogyakarta: Pustaka Pelajar.

Zarkasyi, H.F. 2015. Sistim Pendidikan dan Pengkajian Islam di Pesantren dalam Kontek Dinamika Studi Islam Internasional. EDUKASI: Jurnal Peneliti an Pendidikan Agama dan Keagamaan, Volume 13, Nomor 3, Desember: 335-348. 